\title{
Short-term add-on therapy with angiotensin recep- tor blocker for end-stage inotrope-dependent heart failure patients: B-type natriuretic peptide reduction in a randomized clinical trial
}

\author{
Marcelo E. Ochiai, Euler C. O. Brancalhão, Raphael S. N. Puig, Kelly R. N. Vieira, Juliano N. Cardoso, Múcio \\ Tavares de Oliveira-Jr, Antonio C. P. Barretto
}

Universidade de São Paulo, Heart Institute (InCor), Cotoxó Hospital, São Paulo/SP, Brazil.

\begin{abstract}
OBJECTIVE: We aimed to evaluate angiotensin receptor blocker add-on therapy in patients with low cardiac output during decompensated heart failure.

METHODS: We selected patients with decompensated heart failure, low cardiac output, dobutamine dependence, and an ejection fraction $<0.45$ who were receiving an angiotensin-converting enzyme inhibitor. The patients were randomized to losartan or placebo and underwent invasive hemodynamic and B-type natriuretic peptide measurements at baseline and on the seventh day after intervention. ClinicalTrials.gov: NCT01857999.

RESULTS: We studied 10 patients in the losartan group and 11 patients in the placebo group. The patient characteristics were as follows: age 52.7 years, ejection fraction $21.3 \%$, dobutamine infusion $8.5 \mathrm{mcg} / \mathrm{kg} . \mathrm{min}$, indexed systemic vascular resistance 1918.0 dynes.sec/ $\mathrm{cm}^{5} \cdot \mathrm{m}^{2}$, cardiac index $2.8 \mathrm{~L} / \mathrm{min} . \mathrm{m}^{2}$, and B-type natriuretic peptide $1,403 \mathrm{pg} / \mathrm{mL}$. After 7 days of intervention, there was a $37.4 \%$ reduction in the B-type natriuretic peptide levels in the losartan group compared with an $11.9 \%$ increase in the placebo group (mean difference, $49.1 \%$; $95 \%$ confidence interval: -88.1 to $-9.8 \%, p=0.018$ ). No significant difference was observed in the hemodynamic measurements.

CONCLUSION: Short-term add-on therapy with losartan reduced B-type natriuretic peptide levels in patients hospitalized for decompensated severe heart failure and low cardiac output with inotrope dependence.

KEYWORDS: Renin-Aldosterone System; Hemodynamic; Low Cardiac Output; Vasodilation; Natriuretic Peptide.

Ochiai ME, Brancalhão EC, Puig RS, Vieira KR, Cardoso JN, Oliveira-Jr MT, et al. Short-term add-on therapy with angiotensin receptor blocker for end-stage inotrope-dependent heart failure patients: B-type natriuretic peptide reduction in a randomized clinical trial. Clinics. 2014;69(5):308313.

Received for publication on July 1, 2013; First review completed on August 8, 2013; Accepted for publication on September 27, 2013

E-mail: marcelo.ochiai@incor.usp.br

Tel.: 5511 2661-5417
\end{abstract}

\section{INTRODUCTION}

The management approach for stable chronic heart failure has been established by guidelines (1) that were developed using data from randomized clinical trials. However, during heart failure, decompensation-specific interventions have not been well studied. Moreover, heart failure patients require hospitalization, and sometimes they are in critical condition, presenting problems such as a low cardiac

Copyright (c) 2014 CLINICS - This is an Open Access article distributed under the terms of the Creative Commons Attribution Non-Commercial License (http:// creativecommons.org/licenses/by-nc/3.0/) which permits unrestricted noncommercial use, distribution, and reproduction in any medium, provided the original work is properly cited.

No potential conflict of interest was reported.

DOI: $10.6061 /$ clinics/2014(05)02 output. In this context, fewer clinical trials have been performed.

The intravenous administration of inotropes may be necessary for heart failure patients with low cardiac output if intravenous vasodilator therapy is not possible (2). In endstage heart failure, patients frequently become dependent on inotrope, which predicts greater mortality (3). Generally, these patients die if they cannot receive a heart transplant, either because of clinical conditions or because of the lack of available donor organs. Therefore, it is important to find alternative options so that inotropes can be withdrawn as soon as possible.

During decompensated heart failure, activation of the renin-angiotensin-aldosterone system persists, with increases in plasma renin activity and serum levels of angiotensin II and aldosterone, despite the use of angiotensin-converting enzyme (ACE) inhibitors (4). In advanced heart failure patients, a state of low cardiac output could be present 
during a decompensated period; consequently, the use of ACE inhibitors might not be adequate for controlling vasoconstriction (5).

Although many clinical trials have been performed to examine drug therapies for stable chronic heart failure, clinical trials are lacking for drug therapy during decompensated heart failure, mainly with inotrope dependence (6). In this context, short-term outcomes should have priority (7).

The dual blockade of the renin-angiotensin-aldosterone system with an ACE inhibitor and an AT1 angiotensin receptor blocker (ARB) used together has been demonstrated to be beneficial in heart failure patients $(8,9)$. However, this dual inhibition has not been studied during heart failure decompensation or even when low cardiac output is present.

The objective of this study was to assess the effects of addon therapy with angiotensin receptor blocker on plasma Btype natriuretic peptide (BNP) levels and hemodynamic measurements in heart failure patients with low cardiac output during hospitalization for decompensation.

\section{METHODS}

This study was carried out in the heart failure compensation unit of a tertiary cardiology center at a university hospital. Patients who are typically hospitalized in our medical facility are those with severe advanced heart failure in a decompensation period that does not respond to initial therapy; frequently, these patients present with low cardiac output (10). In our service, dobutamine is preferred over milrinone. It is not uncommon for some patients to experience dobutamine dependence and not be able to tolerate inotropic withdrawal.

\section{Patients}

This was a randomized, double-blind, placebo-controlled clinical trial. The inclusion criteria were as follows: hospitalization for decompensated heart failure, defined by worsening of symptoms until fatigue or dyspnea at rest; low cardiac output, defined by the clinical-hemodynamic profile (4); dobutamine dependence; ejection fraction $<0.45$; spontaneous breathing; and receiving ACE inhibitors. The patients could have jugular ingurgitation, lower limb edema, ascites, and rales. Dobutamine dependence was defined by infusion for more than 15 days or an unsuccessful attempt at withdrawal. The exclusion criteria were as follows: serum creatinine $>3.0 \mathrm{mg} / \mathrm{dL}$, serum $\mathrm{K}>6.0 \mathrm{mEq} /$ $\mathrm{L}$, systolic blood pressure $<70 \mathrm{~mm} \mathrm{Hg}$, aortic stenosis, and acute coronary syndrome in the previous 2 months. The patients were then assigned by permuted block randomization to 4 groups, stratified by sex, to losartan or placebo. The endpoints were changes in the BNP levels, cardiac index, pulmonary wedge capillary pressure, systemic vascular resistance, and successful withdrawal of dobutamine.

With a power of $80 \%$ and an estimated $45 \%$ reduction in BNP level between losartan and placebo, the calculated sample size was 18 patients. As a secondary endpoint, we estimated rates of successful withdrawal of $17 \%$ and $68 \%$ for patients in the placebo group and the ARB group, respectively, on the basis of our previous study (11).

\section{Intervention procedures}

Patients were allocated to the losartan or placebo group. Losartan or placebo was administered at $25 \mathrm{mg}$ bid and increased to $50 \mathrm{mg}$ bid 3 days later. The procedures were performed in a double-blind fashion for the first 7 days to control hemodynamic effects and for at least 3 more days until the attempt at dobutamine withdrawal. Captopril was the standardized ACE inhibitor used and was maintained unchanged during the double-blind period.

\section{Hemodynamic monitoring}

The patients underwent pulmonary artery catheterization, and cardiac output was obtained using the thermodilution technique (12). The hemodynamic data obtained included cardiac index, pulmonary artery pressure, pulmonary capillary wedge pressure, and right atrium pressure. Indexed systemic vascular resistance and indexed pulmonary vascular resistance were calculated. Hemodynamic measurements were performed at baseline and 7 days after the start of the intervention. The patients retained a percutaneous sheath introducer, and pulmonary artery catheters were used only for these two measurements.

BNP levels were measured using the automated immunoassay method at baseline and 7 days later. BNP serum levels were transformed by logarithmic correction. Subsequently, the changes incurred in the losartan and placebo groups were assessed by repeated-measures ANOVA.

\section{Adverse events}

Adverse events included the occurrence of hypotension (systolic blood pressure below $70 \mathrm{~mm} \mathrm{Hg}$ ), hyperkalemia (K above $6.0 \mathrm{mEq} / \mathrm{L}$ ), and worsening renal function (serum creatinine above $3.0 \mathrm{mg} / \mathrm{dL}$ ). If the systolic blood pressure dropped below $70 \mathrm{mmHg}$, the daily dose of losartan or placebo was reduced by half. If this hypotension persisted, losartan or placebo was suspended.

\section{Statistical analysis}

The analysis was performed on an intention-to-treat basis and included all randomized patients. Continuous variables are expressed as the mean and standard deviation and were compared between the ARB and control groups by Student's $t$ test. Categorical variables are expressed as numbers and proportions and were compared using the chisquare test or Fisher's test. Continuous variables at baseline and after the intervention were analyzed between groups using repeated measures ANOVA (13). P-values $<0.05$ (2tailed) were considered significant.

Clinical interest variables or variables with $p<0.100$ by bivariate analysis underwent multivariate analysis by logistic regression (14) to calculate the odds ratios and respective 95\% confidence intervals. Event free survival curves were constructed using the Kaplan-Meier method (15) and compared using the log-rank test (16). The mortality predictors were identified by Cox regression (17).

This study was approved by the research ethics committee of our institution and is registered with the Brazilian Health Ministry and with the Clinical Trials (www.clinicaltrials.gov; NCT 01857999). The patients or their guardians read and signed the informed consent form. This study was conducted according the principles of the Helsinki Declaration (2004).

\section{- RESULTS}

We selected 21 patients between August 2008 and December 2010. The characteristics of the included patients 
were as follows: age $52.7(\mathrm{SD}=11.5)$ years, ejection fraction $21.3 \%(\mathrm{SD}=5.8)$, dobutamine infusion $8.5(\mathrm{SD}=3.8) \mathrm{mcg} /$ kg.min, systolic blood pressure $98.5(\mathrm{SD}=12.2) \mathrm{mmHg}$, pulmonary wedge capillary pressure $30.7(\mathrm{SD}=7.7) \mathrm{mmHg}$, indexed systemic vascular resistance 1,918 $(\mathrm{SD}=556)$ dynes.sec.cm ${ }^{-5} \cdot \mathrm{m}^{-2}$, systemic vascular resistance 1,132 $(\mathrm{SD}=371)$ dynes.sec. $\mathrm{cm}^{-5}$, cardiac index $2.8(\mathrm{SD}=0.7) \mathrm{L} /$ min. $\mathrm{m}^{2}$, and BNP 1,403 $(\mathrm{SD}=950) \mathrm{pg} / \mathrm{mL}$. There were 10 (47.6\%) patients with Chagas disease. See Table 1 for the complete baseline characteristics.

After 7 days, the BNP levels decreased (Figure 1) by 37.4\% in the losartan group and increased by $11.9 \%$ in the placebo group (mean difference $-49.1 \%$; $95 \% \mathrm{CI}$ : -88.1 to $-9.8 \%$, $p=0.018)$.

There was no significant difference in the hemodynamic measurements. The systolic blood pressure decreased by $5.9 \%$ in the losartan group and by $3.2 \%$ in the placebo group $(p=0.796)$. The indexed systemic vascular resistance decreased by $7.7 \%$ in the losartan group vs. $10.5 \%$ in the placebo group $(p=0.280)$. The cardiac index increased by $6.7 \%$ and $6.9 \%$ in losartan and placebo groups, respectively $(p=0.203)$. The pulmonary capillary wedge pressure decreased by $22.9 \%$ and $5.1 \%$ in the losartan and placebo groups, respectively $(p=0.459)$. There were no complications related to the pulmonary artery catheter.

Successful dobutamine withdrawal occurred in $4 / 10$ $(40 \%)$ patients in the losartan group vs. 3/11 (27.3\%) patients in the placebo group $(p=0.537$ by logistic regression). The odds ratio was 1.78 (95\% CI: 0.20 to 16.4$)$ for successful dobutamine withdrawal in the losartan group.

The occurrence of adverse events was similar in both groups. A drop in systolic blood pressure below $70 \mathrm{~mm} \mathrm{Hg}$ occurred in $3(30 \%)$ patients in the losartan group and in 1 $(9.1 \%)$ patient in the placebo group $(p=0.223)$; however, no persistent hypotension occurred. None of the patients in either group had hyperkalemia. Two patients (one patient from each group) had an increase in serum creatinine $(>0.3 \mathrm{mg} / \mathrm{dL})(p=0.943)$. See Table 2 for changes in the laboratory measurements.

After a follow-up of 465 days (95\% CI: 317 to 613$), 10$ patients died ( 5 in each group) $(p=0.640)$, as shown in Figure 2. Cox regression identified heart failure with ischemic etiology as an independent predictor of all-cause

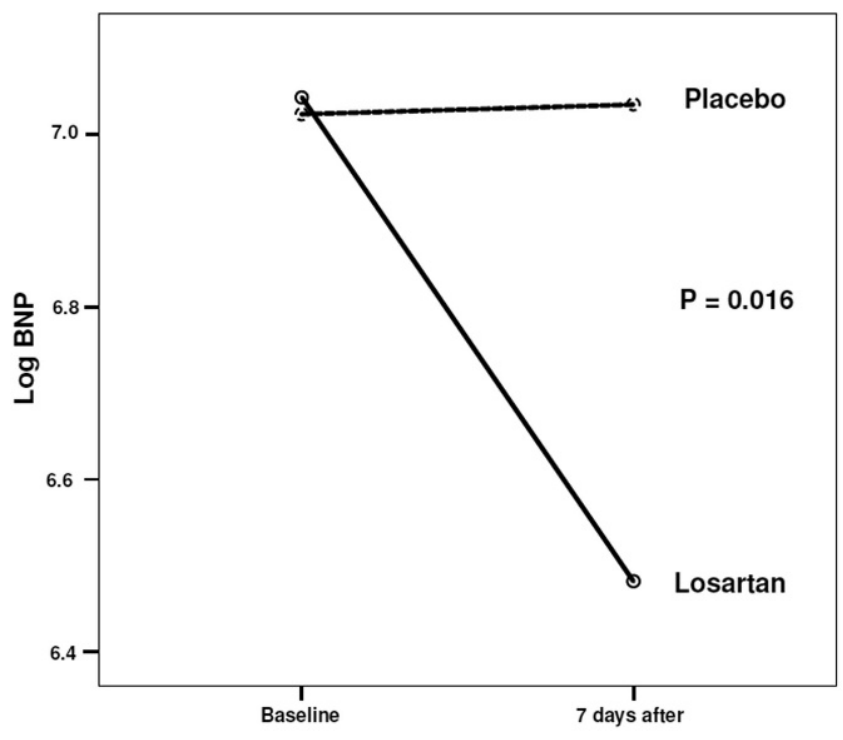

Figure 1 - BNP evolution according to losartan or placebo group.

mortality, with a relative risk of 14.3 (95\% confidence interval: 1.6 to $130.0, p=0.019)$.

\section{DISCUSSION}

The main finding of this study was the decline in BNP levels with angiotensin-receptor blocker add-on therapy in patients with acute decompensated heart failure and a low cardiac output state. Systemic vascular resistance, cardiac index, and pulmonary wedge capillary pressure remained unchanged, as did the clinical endpoint. These findings are based on 42 hemodynamic and BNP measurements in 21 patients.

The novelty of the present study lies in the demonstration of a more intense reduction in BNP levels (37.4\%) with addon ARB therapy during decompensation (compared with $25 \%$ in stable outpatients). Moreover, this effect was achieved in a 7-day period, whereas a 22-week period was reported in a previous study (18). In another study with stable class II-III heart failure patients, candesartan add-on

Table 1 - Baseline characteristics.

\begin{tabular}{|c|c|c|}
\hline Characteristic & Losartan $(\mathrm{N}=10)$ & Placebo $(\mathrm{N}=11)$ \\
\hline Age (SD); years & $48.1(12.7)$ & $55.7(9.8)$ \\
\hline Men $(\%)$ & $8(80)$ & $8(72.7)$ \\
\hline Ejection fraction (SD); \% & $20.4(4.2)$ & $22.1(6.9)$ \\
\hline Dobutamine dose (SD); $\mathrm{mcg} \cdot \mathrm{kg}^{-1} \cdot \mathrm{min}^{-1}$ & $7.2(2.8)$ & $9.6(4.3)$ \\
\hline Cardiac index (SD); L. $\min ^{-1} \cdot \mathrm{m}^{-2}$ & $2.98(0.36)$ & $2.64(0.86)$ \\
\hline Indexed systemic vascular resistance (SD); dynes.sec. $\mathrm{cm}^{-5} \cdot \mathrm{m}^{-2}$ & $1,755(294)$ & $2,052(689)$ \\
\hline Systemic vascular resistance (SD); dynes.sec. $\mathrm{cm}^{-5}$ & $1,022(244)$ & $1,234(445)$ \\
\hline Pulmonary wedge capillary pressure (SD); $\mathrm{mmHg}$ & $30.0(4.6)$ & $31.2(9.8)$ \\
\hline Captopril dose (SD); mg/d & $138.8(35.6)$ & $129.6(35.0)$ \\
\hline Carvedilol (\%) & $6(60.0)$ & $9(81.9)$ \\
\hline Furosemide (\%) & $9(90)$ & $10(91)$ \\
\hline Sodium (SD); mEq/L & $133.2(3.7)$ & $134.3(4.3)$ \\
\hline Potassium (SD); mEq/L & $4.23(0.41)$ & $4.12(0.43)$ \\
\hline Urea (SD); mg/dL & $63.8(35.8)$ & $59.4(18.3)$ \\
\hline Creatinine (SD); mg/dL & $1.21(0.44)$ & $1.25(0.30)$ \\
\hline BNP; median (interquartile range); $\mathrm{pg} / \mathrm{mL}$ & $1,259.5(718.5$ to $2,035.0)$ & $1,046.5(604.5$ to $2,061.0)$ \\
\hline Hemoglobin (SD); g/dL & $13.4(1.2)$ & $11.4(1.0)$ \\
\hline
\end{tabular}

SD: standard deviation; BNP: B-type natriuretic peptide. 
Table 2 - Changes in variables.

\begin{tabular}{|c|c|c|c|}
\hline Variable & Losartan $(\mathrm{N}=10)$ & Placebo $(\mathrm{N}=11)$ & $p$-value \\
\hline Potassium (SD); $\mathrm{mEq} / \mathrm{L}$; at baseline & $4.2(0.4)$ & $4.1(0.4)$ & \\
\hline Potassium (SD); $\mathrm{mEq} / \mathrm{L} ;$ on $7^{\text {th }}$ day & $4.3(0.5)$ & $4.3(0.4)$ & 0.959 \\
\hline Creatinine (SD); $\mathrm{mg} / \mathrm{dL}$; at baseline & $1.21(0.44)$ & $1.25(0.30)$ & \\
\hline Creatinine (SD); $\mathrm{mg} / \mathrm{dL}$; on $7^{\text {th }}$ day & $1.15(0.33)$ & $1.15(0.29)$ & 0.911 \\
\hline BNP; median (IQR); $\mathrm{pg} / \mathrm{mL}$; at baseline & $1,259.5(1,318)$ & $1,046.5(1,457)$ & \\
\hline BNP; median (IQR); $\mathrm{pg} / \mathrm{mL}$; on $7^{\text {th }}$ day & $895.5(814)$ & $1,003.0(1001.0)$ & 0.016 \\
\hline
\end{tabular}

SD: standard deviation; BNP: B-type natriuretic peptide; IQR: interquartile range;

$P$-value from inter-group comparison.

therapy reduced amino-terminal proBNP by $20 \%$ in 6 months (19). Different from stable heart failure patients, the management of patients with decompensation requires specific strategies. For this reason, add-on ARB therapy could be more important during heart failure decompensation, when BNP levels and neuro-hormonal activation are higher (4).

A generally low cardiac output state during decompensation of heart failure is often neglected in randomized clinical trials. Moreover, patients with unsuccessful withdrawal of inotropic therapy have mortality rates higher than 79\% (20). Our findings could be particularly important for inotropedependent heart failure patients who are not able to receive a heart transplant. For these patients, the effects of drug therapy should be faster and more intensive than for patients with mild disease.

In addition, the lower ejection fraction, the low cardiac output, the higher systemic vascular resistance, and the higher BNP levels demonstrated the severity of heart failure in our patients.

\section{Hemodynamic condition during heart failure decompensation}

We found high systemic vascular resistance and high pulmonary capillary wedge pressure in our patients during acute heart failure decompensation. The high systemic vascular resistance occurred despite the fact that the patients were taking a high dose of an ACE inhibitor (captopril: $134 \mathrm{mg} / \mathrm{d}$ ). In fact, Parker et al. observed a reduction in systemic vascular resistance in patients with severe heart failure who were taking ACE inhibitors; however, this resistance remained above the normal values $(21,22)$. The cardiac index was normal; however, all patients were using intravenous inotrope. Our findings are similar to those of the Escape trial, which justifies the use of multiple vasodilators with add-on ARB therapy. Interestingly, hemodynamic improvement in the placebo group occurred even though all medications remained unchanged. Non-pharmacological factors could be involved in this finding, such as rest, salt restriction, physiotherapy, and the "inertial" effect of drug therapy before the hemodynamic measurements.

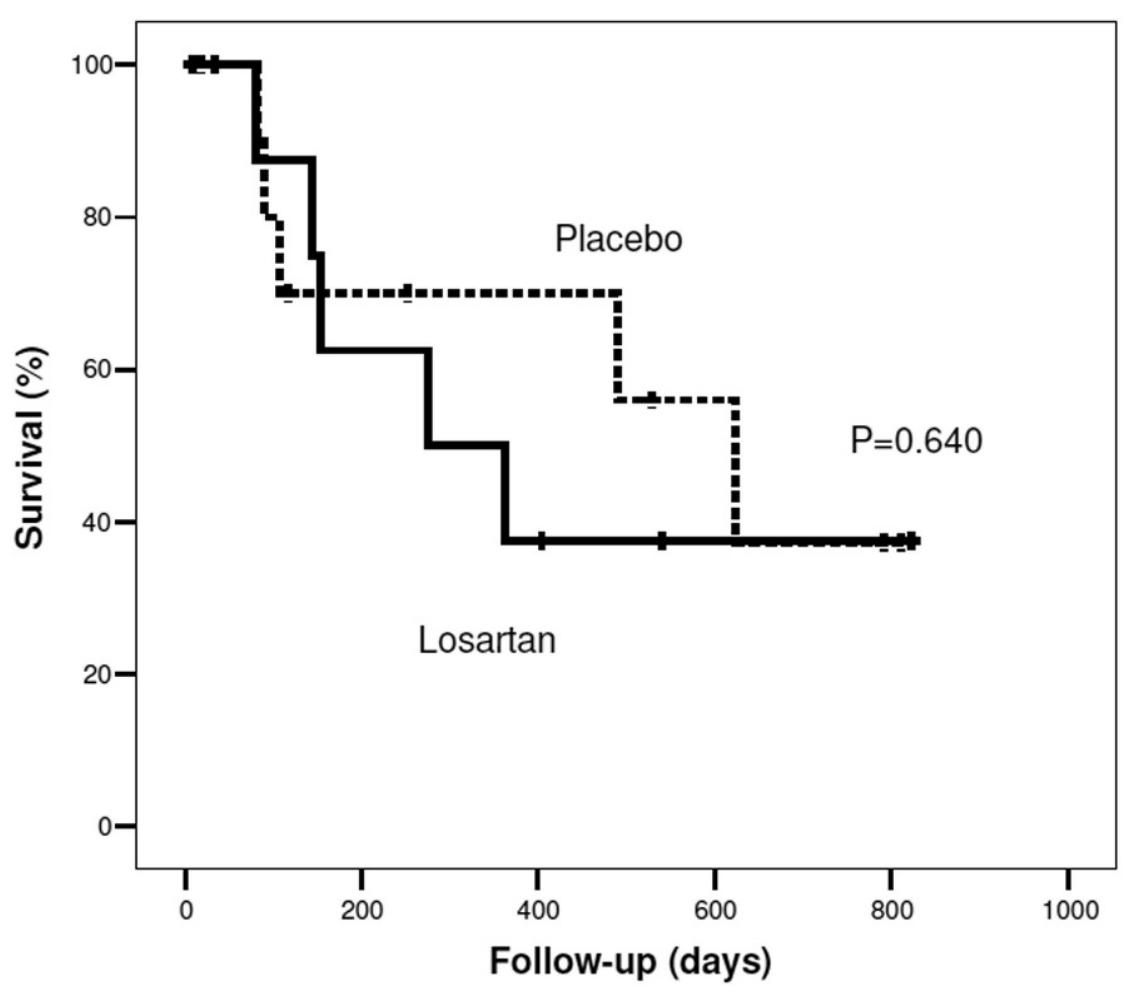

Figure 2 - Survival curves according to losartan or placebo. 
Dobutamine is indicated for low cardiac output in severe heart failure based on International Guidelines; however, a meta-analysis describing concerns regarding the increase in mortality has been published (23). Nevertheless, this metaanalysis included outpatients who received intermittent therapy. Despite these concerns, in practice, physicians continue to prescribe dobutamine to $22.3 \%$ of patients who are hospitalized for heart failure $(24,25)$. Consequently, our results showed that add-on ARB therapy is an alternative to this high-risk situation (i.e., low cardiac state and inotrope dependence).

\section{ARB-ACE inhibitor association pathophysiology}

The renin-angiotensin-aldosterone system plays an important role in the pathophysiology of heart failure. In systolic heart failure, activation of this system occurs, which worsens cardiac remodeling and hemodynamic conditions, creating a vicious cycle. The blockade of this system with an ACE inhibitor and an aldosterone antagonist reduces morbidity and mortality.In addition, the renin-angiotensinaldosterone system interacts with the cardiac peptide system. Plasma BNP levels increase in heart failure due to $\mathrm{BNP}$ release by myocytes after distension. BNP has diagnostic and prognostic values in heart failure (26). Used as a guide for heart failure treatment, BNP reduces death, hospital admission, and decompensation, most likely through higher doses of diuretics, ACE inhibitors, and spironolactone $(27,28,29)$. However, the use of biomarkers such as BNP as a surrogate endpoint remains controversial.

The ARB-ACE inhibitor association has been proven to be beneficial in reducing clinical events such as cardiovascular mortality and hospitalization $(8,9)$. In our study, we applied the tactic of ARB add-on therapy in patients with more severe heart failure during decompensation and low cardiac output, and we found a hormonal benefit. The survival analysis did not identify a difference between the losartan and placebo groups; however, the procedures were performed in a double-blind fashion for 7 days, and it is very unlikely that a short-term intervention could have an influence on late outcomes.

The HEAAL study demonstrated that a high dose of losartan reduces the endpoint rate compared with a low dose (30). The occurrence of hyperkalemia was $2.79 \%$ in the high-dose group and $1.87 \%$ in the low-dose group $(p<0.001)$; creatinine was also increased in the high-dose group $(7.12 \%)$ compared with the low-dose group $(4.73 \%)$ $(p<0.001)$.

This association has been demonstrated to be beneficial for patients on hemodialysis, leading to a significant reduction in mortality and hospitalization (31). Adverse effects-mainly hypotension-occurred in $16.3 \%$ of patients in the ARB group versus $10.7 \%$ of patients in the placebo group.

\section{Safety of the ARB-ACE inhibitor association}

Safety is another concern related to the ARB-ACE inhibitor association. In the present study, the ARB-ACE inhibitor association did not increase the occurrence of adverse effects in the short-term. Use of this association for treatment of hypertension did not reduce cardiovascular events; rather, it increased adverse effects (32). On the other hand, in heart failure patients, this association decreased mortality and hospitalization with an increase of approximately $5 \%$ in adverse effects $(8,9)$. In addition, a meta-analysis (33) revealed a $2.3 \%$ increase in the risk of developing an adverse event. However, patients with more advanced heart failure are the minority in these studies. The occurrence of adverse events could be more frequent in patients with more severe disease, although the benefit could be greater. Moreover, worsening renal function has special importance because it has been related to a worse prognosis in severe heart failure (34).

\section{Study limitations}

The sample size of our study was small; thus, the analysis of clinical events was somewhat challenging. Our primary endpoint was a change in BNP, which is a surrogate endpoint for clinical events. It is possible that the high percentage of Chagas disease cardiomyopathy interfered with our results because these patients have attenuated vasoconstriction; consequently, multiple vasodilation strategies were not as effective as we expected.

In summary, short-term add-on therapy with losartan reduced BNP levels in patients hospitalized for decompensated severe heart failure and low cardiac output with inotrope dependence. A non-significant hemodynamic improvement and an increase in the probability of successful dobutamine withdrawal were observed.

\section{ACKNOWLEDGMENTS}

This study was sponsored by the São Paulo Research Foundation (FAPESP - grant number 2006/06463-9).

\section{- AUTHOR CONTRIBUTIONS}

Ochiai ME conceived the study and performed patient selection, invasive monitoring, and manuscript writing. Brancalhão EC and Puig RS performed patient selection, invasive monitoring, and data analysis. Vieira KR reviewed the literature and performed patient selection as well as invasive monitoring. Cardoso JN performed patient selection and invasive monitoring and provided helpful suggestions. Oliveira-Jr MT assisted with manuscript writing. Barretto AC assisted with conception of the study and manuscript writing.

\section{REFERENCES}

1. Jessup M, Abraham WT, Casey DE, Feldman AM, Francis GS, Ganiats TG, et al. 2009 Focused Update: ACCF/AHA Guidelines for the Diagnosis and Management of Heart Failure in Adults: A Report of the American College of Cardiology Foundation/American Heart Association Task Force on Practice Guidelines Developed in Collaboration With the International Society for Heart and Lung Transplantation. Circulation. 2009;119(14):1977-2016.

2. McMurray JJ, Adamopoulos S, Anker SD, Auricchio A, Bohm M, Dickstein K, et al. ESC Guidelines for the diagnosis and treatment of acute and chronic heart failure 2012. The Task Force for the Diagnosis and Treatment of Acute and Chronic Heart Failure 2012 of the European Society of Cardiology. Developed in collaboration with the Heart Failure Association (HFA) of the ESC. Eur J Heart Fail. 2012;14(8):803-69.

3. Ochiai ME, Cardoso JN, Vieira KR, Lima MV, Brancalhao EC, Barretto AC. Predictors of low cardiac output in decompensated severe heart failure. Clinics. 2011;66(2):239-44, http://dx.doi.org/10.1590/S180759322011000200010.

4. Johnson W, Omland T, Hall C, Lucas C, Myking OL, Collins C, et al. Neurohormonal activation rapidly decreases after intravenous therapy with diuretics and vasodilators for class IV heart failure. J Am Coll Cardiol. 2002;39(10):1623-9, http://dx.doi.org/10.1016/S0735-1097(02) 01814-4.

5. Mullens W, Abrahams Z, Francis GS, Sokos G, Starling RC, Young JB, et al. Usefulness of isosorbide dinitrate and hydralazine as add-on therapy in patients discharged for advanced decompensated heart failure. Am J Cardiol. 2009;103(8):1113-9, http://dx.doi.org/10.1016/j. amjcard.2008.12.028.

6. Felker GM, Pang PS, Adams KF, Cleland JG, Cotter G, Dickstein K, et al. Clinical trials of pharmacological therapies in acute heart failure syndromes: lessons learned and directions forward. Circ Heart Fail. 
2010;3(2):314-25, http:/ /dx.doi.org/10.1161/CIRCHEARTFAILURE.109. 893222 .

7. Gheorghiade M, De Luca L, Fonarow GC, Filippatos G, Metra M, Francis GS. Pathophysiologic targets in the early phase of acute heart failure syndromes. Am J Cardiol. 2005;96(6A):11G-17G, http://dx.doi.org/10. 1016/j.amjcard.2005.07.016

8. McMurray JJ, Östergren J, Swedberg K, Granger CB, Held P, Michelson EL, et al. Effects of candesartan in patients with chronic heart failure and reduced left-ventricular systolic function taking angiotensin-convertingenzyme inhibitors: the CHARM-Added trial. Lancet. 2003;362(9386):76771, http:/ /dx.doi.org/10.1016/S0140-6736(03)14283-3.

9. Cohn JN, Tognoni G, for the Valsartan Heart Failure Trial Investigators. A randomized trial of the angiotensin-receptor blocker valsartan in chronic heart failure. N Engl J Med. 2001;345(23):1667-75.

10. Cardoso J, Novaes M, Ochiai M, Regina K, Morgado P, Munhoz R, et al. Chagas cardiomyopathy: prognosis in clinical and hemodynamic profile C. Arq Bras Cardiol. 2010;95(4):518-23, http://dx.doi.org/10.1590/S0066782X2010005000112.

11. Ochiai ME, Barretto AC, Cardoso JN, Munhoz RT, Morgado PC, Ramires JA. Angiotensin II receptor blocker add-on therapy for low cardiac output in decompensated heart failure. Arq Bras Cardiol. 2010;94(2):21922.

12. Voyce SJ, Urbach D, Rippe JM. Pulmonary artery catheters. In: Rippe JM, Irwin RS, Alpert JS, Fink MP (eds). Intensive Care Medicine 2nd ed. Little, Boston: Brown and Company; 1991. p. 48-72.

13. Diggle PJ. An approach to the analysis of repeated measurements. Biometrics. 1988;44(4):959-71, http:/ /dx.doi.org/10.2307/2531727.

14. Hosmer DW, Lemeshow S. Applied Logistic Regression. New York: Wiley. 1989.

15. Kaplan EL, Meier P. Nonparametric estimation from incomplete observations. J Am Stat Assoc. 1958;53:457-81, http://dx.doi.org/10. 1080/01621459.1958.10501452.

16. Cox DR, Oakes D. Analysis of Survival Data. 1st ed. London: Chapman and Hall. 1984.

17. Cox DR. Regression Models and Life-tables. J Royal Statistical Society. 1972;34(2):187-220.

18. Mitrovic V, Appel KF, Proskynitopoulos N, Dereli S, Hamm CW. Effects of candesartan cilexetil "add-on" treatment in congestive heart failure outpatients in daily practice. Clin Res Cardiol. 2009;98(6):379-89, http:/ / dx.doi.org/10.1007/s00392-009-0011-7.

19. White M, Lepage S, Lavoie J, De Denus S, Leblanc MH, Gossard D, et al. Effects of combined candesartan and ACE inhibitors on BNP, markers of inflammation and oxidative stress, and glucose regulation in patients with symptomatic heart failure. J Card Fail. 2007;13(2):86-94, http://dx. doi.org/10.1016/j.cardfail.2006.10.013.

20. Caccamo MA, Eckman PM. Pharmacologic therapy for New York Heart Association class IV heart failure. Congest Heart Fail. 2011;17(5):213-9, http://dx.doi.org/10.1111/j.1751-7133.2011.00235.x.

21. Packer M, Lee WH, Medina N, Yushak M, Kessler PD. Functional renal insufficiency during long-term therapy with captopril and enalapril in severe chronic heart failure. Ann Intern Med. 1987;106(3):346-54, http:/ / dx.doi.org/10.7326/0003-4819-106-3-346.

22. Viecili PR, Pamplona D, Park M, Silva SR, Ramires JA, Da Luz PL. Antagonism of the acute hemodynamic effects of captopril in decompensated congestive heart failure by aspirin administration. Braz J Med Biol Res. 2003;36(6):771-80, http://dx.doi.org/10.1590/S0100-879X2003000600013.

23. Tacon CL, McCaffrey J, Delaney A. Dobutamine for patients with severe heart failure: a systematic review and meta-analysis of randomised controlled trials. Intensive Care Med. 2012;38(3):359-67, http://dx.doi. org/10.1007/s00134-011-2435-6.

24. Partovian C, Gleim SR, Mody PS, Li SX, Wang H, Strait KM, et al. Hospital patterns of use of positive inotropic agents in patients with heart failure. J Am Coll Cardiol. 2012;60(15):1402-9, http://dx.doi.org/ 10.1016/j.jacc.2012.07.011.

25. Follath F, Yilmaz MB, Delgado JF, Parissis JT, Porcher R, Gayat E, et al. Clinical presentation, management and outcomes in the Acute Heart Failure Global Survey of Standard Treatment (ALARM-HF). Intensive Care Med. 2011;37(4):619-26, http://dx.doi.org/10.1007/s00134-0102113-0.

26. Mentz RJ, Felker GM. Natriuretic peptide-guided therapy for heart failure. Circ J. 2011;75(9):2031-7.

27. Troughton RW, Frampton CM, Yandle TG, Espiner EA, Nicholls MG, Richards AM. Treatment of heart failure guided by plasma aminoterminal brain natriuretic peptide (N-BNP) concentrations. Lancet. 2000;355 (9210):1126-30, http:/ / dx.doi.org/10.1016/S0140-6736(00)02060-2.

28. Jourdain P, Jondeau G, Funck F, Gueffet P, Le Helloco A, Donal E, et al. Plasma brain natriuretic peptide-guided therapy to improve outcome in heart failure: the STARS-BNP Multicenter Study. J Am Coll Cardiol. 2007;49(16):1733-9, http://dx.doi.org/10.1016/j.jacc.2006.10.081.

29. Berger R, Moertl D, Peter S, Ahmadi R, Huelsmann M, Yamuti S, et al. Nterminal pro-B-type natriuretic peptide-guided, intensive patient management in addition to multidisciplinary care in chronic heart failure a 3-arm, prospective, randomized pilot study. J Am Coll Cardiol. 2010; 55(7):645-53, http://dx.doi.org/10.1016/j.jacc.2009.08.078.

30. Konstam MA, Neaton JD, Dickstein K, Drexler H, Komajda M, Martinez FA, et al. Effects of high-dose versus low-dose losartan on clinical outcomes in patients with heart failure (HEAAL study): a randomised, double-blind trial. Lancet. 2009;374(9704):1840-8, http://dx.doi.org/10. 1016/S0140-6736(09)61913-9.

31. Cice G, Di Benedetto A, D'Isa S, D'Andrea A, Marcelli D, Gatti E, et al. Effects of telmisartan added to Angiotensin-converting enzyme inhibitors on mortality and morbidity in hemodialysis patients with chronic heart failure a double-blind, placebo-controlled trial. J Am Coll Cardiol. 2010;56(21):1701-8, http://dx.doi.org/10.1016/j.jacc.2010.03.105.

32. Yusuf S, Teo KK, Pogue J, Dyal L, Copland I, Schumacher H, et al. Telmisartan, ramipril, or both in patients at high risk for vascular events. N Engl J Med. 2008;358(15):1547-59.

33. Lakhdar R, Al-Mallah MH, Lanfear DE. Safety and tolerability of angiotensin-converting enzyme inhibitor versus the combination of angiotensin-converting enzyme inhibitor and angiotensin receptor blocker in patients with left ventricular dysfunction: a systematic review and meta-analysis of randomized controlled trials. J Card Fail. 2008;14(3):181-8, http:/ /dx.doi.org/10.1016/j.cardfail.2007.11.008.

34. Ochiai ME, Barretto AC, Oliveira MT Jr, Munhoz RT, Morgado PC, Ramires JA. Uric acid renal excretion and renal insufficiency in decompensated severe heart failure. Eur J Heart Fail. 2005;7(4):46874 . 